\title{
PRE-SERVICE EFL TEACHERS' SELF-EFFICACY BELIEFS, GOAL ORIENTATIONS, AND PARTICIPATIONS IN AN ONLINE LEARNING ENVIRONMENT
}

\author{
Hasan UCAR \\ Bilecik Seyh Edebali University, Bilecik, Turkey \\ Prof. Dr. Mujgan YAZICI BOZKAYA \\ Open Education Faculty \\ Anadolu University, Eskisehir, Turkey
}

\section{ABSTRACT}

This study examined the pre-service EFL teachers' self-efficacy beliefs, goal orientations, and participations in an online learning environment. Embedded mixed design was used in the study. In the quantitative part of the study, the participants were 186 senior pre-service EFL teachers and data were collected on two scales and a questionnaire. Qualitative data were collected in form of one-on-one interviews from 2 pre-service EFL teachers, the most representative of the population, to understand the motivation and behaviour variables. The findings of this research revealed that pre-service EFL teachers' self-efficacy believes are high but fragile. However, some of the participants had more than one goal orientation. The mastery and performance oriented pre-service teachers displayed different characteristics of motivation. Moreover, few of the pre-service EFL teachers participate in the online learning environment. Results also showed several positive associations between teachers' goal orientations and self-efficacy beliefs. The results as well as their implications are discussed and suggestions for future research are presented.

Keywords: Pre-service EFL teacher, self-efficacy, achievement goal orientation

\section{INTRODUCTION}

Teachers' self-efficacy beliefs and goal orientations have significant implications in education settings. Teachers are one of the most important components in education systems. Their beliefs and attitudes during education process affect their behaviours in teaching (Bandura, 1997). Recent studies done in the field of education have showed that knowledge and skills are not adequate for active teaching. Teachers' attitudes and beliefs have also been found to be contributing to their effectiveness as educators (Bandura, 1997; Tschannen-Moran, Woolfolk Hoy, \& Hoy, 1998). Even though there are many studies on students' motivation for learning, there has been little research on teachers' motivation for teaching (Retelsdorf, Butler, Streblow, \& Schiefele, 2010).

One of main objective in education process is to reach a goal. To achieve this goal, many variables interact with each other. The main variables that affect the teachers, the learners, and the teaching and learning environment are self-efficacy and goal orientation constructs. The first construct, self-efficacy belief, has been mostly studied in education area in the last two decades. Self-efficacy belief refers to perception of one's own ability in organizing and completing a task successfully (Bandura, 1997). It has been applied to understanding how teachers' thoughts about their competence in classroom teaching, students' achievement and management of the classroom. Chacon (2005) also reported that teachers' sense of efficacy influences teachers' actions and student outcomes. It is also accepted that one of the most important factors affecting students' perception and 
goal orientation is the teacher (Afsaneh \& Safoura, 2015). Beghetto (2007) and Egel (2009) also stated that it is important for researchers to examine pre-service teachers' efficacy beliefs about student motivation.

Achievement goal orientation is the second construct, which has been pointed to affect the teaching and learning environment in numerous studies. This concept is about purposes and motives that individuals had in a task. This variable has been used to assess the students' motivation for learning but later it has begun to be used to understand the teachers' motivation, as well (Butler, 2007). Kucsera, Roberts, Walls, Walker, and Svinicki (2011) reported that achievement goal theory affects many motivation and behaviour variables in the student and work literatures, but it is still applied specifically to teachers and teaching. Nitsche, Dickhäuser, Fasching, and Dresel (2011) reported that teachers' goal orientation is a significant factor for teachers' individual development of competence. According to Retelsdorf et al., (2010) achievement goal construct may also be useful for defining motivation of pre-service teachers.

Pre-service teachers, when compared with experienced in-service teachers, are in closer touch with updated teaching approaches and in fact, often bring information about new methodologies to the in-service teachers through teaching practicum (Tang, Lee \& Chun, 2012). However, pre-service teachers' achievement goals and efficacy belief may change in terms of learning environments. To date, no study has researched online distance preservice EFL teachers' psychological incentives, achievement goals, and efficacy belief. In the present study, we attempt to examine the mentioned variables and assess the relationships between pre-service teachers' participation in an online learning environment and psychological incentives, achievement goals and efficacy belief. This may help those concerned both educators and administrators in making policy decisions about the learning environment in order to maintain or increase psychological incentives of the pre-service ELT teachers.

\section{LITERATURE REVIEW}

Historically, the first theory that influenced the first studies on teacher efficacy was grounded in Rotter's social learning theory (Tschannen-Moran, Woolfolk Hoy \& Hoy, 1998). This theory also known as Rotter's locus of control. Locus of control defined teacher efficacy as the extent to which teachers believed that they could control events that affect them. There are two kinds of locus of control, internal locus of control and external locus of control. Teachers with internal locus of control believe that their own actions determine the outcomes they obtain, while teachers with external locus of control believe that their experiences are not determined by themselves but by sources outside themselves like chance, and fate.

Bandura's social cognitive theory (1997) is another theory, which has been shown to have a connection to the educational psychology for the last two decades. Bandura's theory consists of three components: human agency, outcome expectancy, and efficacy belief. As Bandura (1997) defined self-efficacy belief is "the beliefs in one's capabilities to organize and execute the course of action required to produce given attainments". According to Bandura, self-efficacy belief affects individuals in many ways. If the people have high efficacy, in turn, they will have high effort to accomplish the work that they deal with (Pajares, 2002). Bandura defined teacher efficacy as a kind of efficacy. Tschannen-Moran and Woolfolk Hoy (2001) described teacher efficacy as teachers' belief about their capabilities to get the desired outcomes of student engagement and learning. Henson (2001) stated that teachers' self-efficacy beliefs have been repeatedly associated with positive teaching behaviours and student outcomes. In addition, self-efficacy is even a stronger positive predictor for self-regulation (Daal, Donche, \& Maeyer, 2014). Bandura (1997) stated that teachers' efficacy beliefs are generally open to change during the preservice time. Therefore, this construct should be examined deeply. 
Achievement goal theory is the third theory that affects the pre-service teachers. It is very common in the achievement motivation literature. This construct is about the purposes and motives the individuals get in achievement task (Dweck \& Leggett, 1988). It consists of four constructs. These are: mastery-approach, mastery-avoidance, performance-approach, and performance-avoidance achievement goal orientations (Elliot \& Murayama, 2008). Learners with approach goals try to master learning tasks and they do their best to completely acquire the subjects, while students with avoidance goals avoid negative results such as failure while mastering the tasks (Elliot \& McGregor, 2001). In other words, in approach aspects (mastery-approach and performance-approach) learners believe in themselves to do well but in avoidance aspects (performance-avoidance and masteryavoidance) these learners doubt about their ability to perform well (Coutinho \& Neuman, 2008). Kucsera et al., (2011) reported that achievement goal theory affect many motivation and behaviour variables in the student and work literatures, but it is still applied specifically to teachers and teaching. Nitsche et al. (2011) reported that teachers' goal orientations are significant factors for teachers' individual development of competence. Retelsdorf et al. (2010) cited that achievement goal construct may also be useful for defining motivation of pre-service teachers.

The literature provides proofs that self-efficacy and achievement goal orientations are contributing factors of success of learners and pre-service teachers (Afsaneh \& Safoura, 2015; Bandura, 1997; Coutinho \& Neuman, 2008; Elliot \& McGregor, 2001). However, there is a gap in the literature that identifies and links self-efficacy and achievement goal orientation to online pre-service EFL teachers. This study adds evidence and knowledge to the literature.

Goal of the Study and Research Questions

The study aimed to explore pre-service EFL teachers' self-efficacy beliefs, goal orientations, and participation in the online learning environment and examine the relationships among these variables.

The research questions that guide this research are as follows:

$>$ What is the level of self-efficacy beliefs of the pre-service EFL teachers?

$>$ What kind of achievement goal orientations do the pre-service EFL teachers have?

$>$ Is there a relationship between the pre-service EFL teachers' self-efficacy beliefs and achievement goal orientations?

$>$ Do pre-service EFL teachers' self-efficacy beliefs change according to status of participation in the online learning environment?

$>$ Do pre-service EFL teachers' achievement goal orientations change according to status of participation in the online learning environment?

\section{METHOD}

\section{Research Design}

Embedded mixed design, which is one of the mixed method design, was used for this study. The purpose of the embedded design is to collect quantitative and qualitative data simultaneously or sequentially, but to have one form of data play a supportive role to the other form of data (Cresswell, 2012:544). In this study a sequential design was used with the embedded design. That is to say, quantitative data as a primary form was used to inform the qualitative phase. For the quantitative part of the study, pre-service EFL teachers who volunteer and who agree attended the study. The data were collected from 186 convenient participants. The representative sample is accepted at $95 \%$ confidence level, $5.95 \%$ margin of error, and $\mathbf{5 0 \%}$ response distribution. Three instruments, namely English Teachers' Sense of Efficacy Scale (ESTES), Achievement Goals Questionnaire-Revised (AGQ-R), and demographic and online learning environment questionnaire were used. The quantitative information represented a major source of information for this study. For the qualitative part, data were collected in the form of one-on-one interviews to understand the beliefs, goals and perceptions of the pre-service teachers at first hand. 


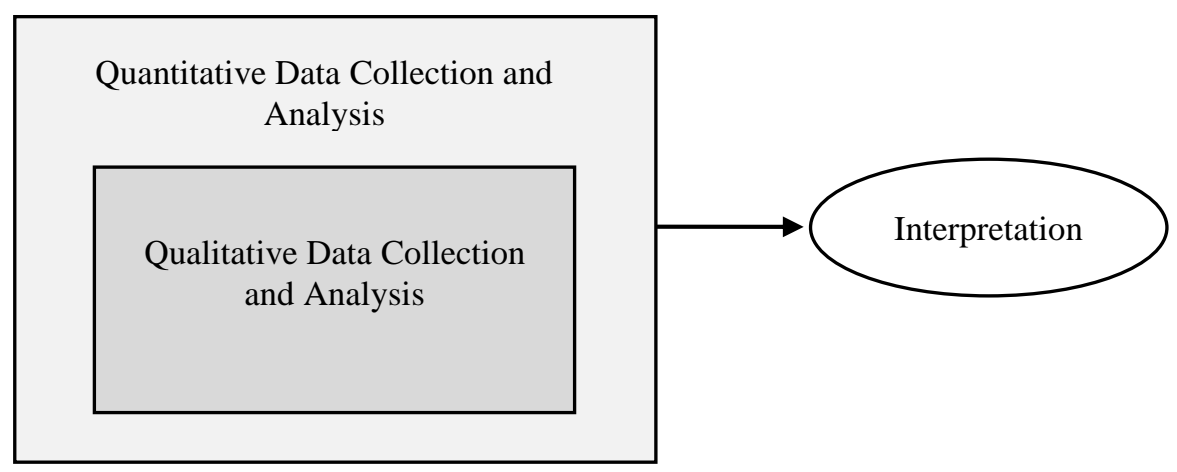

Figure: 1

The study design (Creswell, 2012)

\section{Participants of the Study}

The population consisted of pre-service EFL teachers enrolled at Distance English Language Teacher Education BA program at College of Open Education, Anadolu University in Turkey. This program has a blended model of instruction, supplies both face to face, and distance education. The first two years of the program are conducted mainly through traditional classroom instruction, and the third and fourth years of the program are conducted by means of distance education supported by online courses through the online learning environment, that is asynchronous Web-based course management tool. Online component of the program aims to provide guidance to students. Before the main quantitative study, 38 pre-service EFL teachers consented to participate voluntarily to the face-to-face pilot study. For the main study, 186 pre-service teachers participated. There were 144 females and 42 males students. The age range of the sample was 21 years to 30 years. Table 1 provides the demographic information for the population, and for the sample used in this study. As seen in Table 1, the proportions of the gender and age within the sample are generally representative of the population.

Table: 1

The proportions of the gender and age within the sample and population

\begin{tabular}{ccc}
\hline & $\begin{array}{c}\text { Sample } \\
(\mathrm{n}=186)\end{array}$ & $\begin{array}{l}\text { Population } \\
(\mathrm{N}=588)\end{array}$ \\
\hline $\begin{array}{c}\text { Gender } \\
\text { Female }\end{array}$ & $\mathbf{7 7 . 4 \%}$ & $76.7 \%$ \\
Male & $22.6 \%$ & $23.3 \%$ \\
$\begin{array}{c}\text { Age } \\
21-23\end{array}$ & $53.2 \%$ & $56.7 \%$ \\
$24-30$ & $46.8 \%$ & $43.3 \%$ \\
\hline
\end{tabular}

Qualitative part of the study was consisted of two one-on-one interviews. Participants of the interviews were two pre-service EFL teachers. The participants were purposefully selected from 186 pre-service EFL teachers who completed the English Teachers' Sense of Efficacy Scale (ESTES) and Achievement Goals Questionnaire - Revised (AGQ-R), and the questionnaire. They were selected for the one-on-one interviews because their scores on the scales and the questionnaire identified them as the most representative of the population. 
Table: 2

Features of the participants in the qualitative phase

\begin{tabular}{|c|c|c|c|c|}
\hline $\begin{array}{l}\text { Pre-service EFL } \\
\text { Teachers }\end{array}$ & Gender & $\begin{array}{c}\text { Goal } \\
\text { Orientations }\end{array}$ & $\begin{array}{c}\text { Self- } \\
\text { Efficacy }\end{array}$ & $\begin{array}{c}\text { Use of the Online Learning } \\
\text { Environment }\end{array}$ \\
\hline PST $_{1}$ & Female & $\begin{array}{c}\text { High mastery } \\
\text { Low } \\
\text { performance }\end{array}$ & High & Yes / Active \\
\hline $\mathbf{P S T}_{2}$ & Female & $\begin{array}{c}\text { Low mastery } \\
\text { High } \\
\text { performance }\end{array}$ & Medium & Yes / Not Active \\
\hline
\end{tabular}

Data Collection Instruments

The data were obtained, primarily, via two scales, namely English Teachers' Sense of Efficacy Scale (ESTES) (Chacon, 2005) and Achievement Goals Questionnaire - Revised (AGQ-R) (Elliot \& Murayama, 2008). The participants also responded to the demographic and online learning environment questionnaire. For the qualitative part, data were collected through two one-on-one interviews.

English Teachers' Sense of Efficacy Scale (ESTES) consists of five subscales. In this research, only adapted version of Teachers' Sense of Efficacy Scale (TSES) (TschannenMoran \& Woolfolk Hoy, 2001), with 12 items including four items for each of the three dimensions was used to assess pre-service EFL teachers' self-efficacy beliefs. The measured three subscales are: Teachers' efficacy for engaging students learning in EFL, teachers' perceived efficacy for managing EFL classes, and teachers' perceived efficacy for implementing instructional strategies to teach EFL.

Achievement Goals Questionnaire - Revised (AGQ-R). The AGQ-R is a 12 item, 5-point Likert scale questionnaire used to measure achievement goal orientations namely masteryapproach, mastery-avoidance, performance-approach and performance-avoidance. The demographic information section, which was developed by the researchers, includes questions about gender, age, educational background, and teaching and learning experience of the pre-service EFL teachers. The last part of the questionnaire, which was developed by the researcher and includes both Likert type and open-ended questions, is about the students' perceptions of and participation in online learning environment.

In qualitative one-on-one interviews, open-ended questions below were asked to the preservice EFL teachers:

$>$ How do you describe yourself as a teacher/student?

$>$ What are your goals (personal/academic/professional)?

$>$ What do you do when you faced a very difficult academic task?

$>$ What do you think about the relationship between ability and success?

$>$ What do you do when you faced a challenging situation in the classroom?

$>$ What do you do to get students to believe they can do well in English?

$>$ How do you react when your students are confused?

$>$ Do you participate in online learning environment? What is your intend use of online learning environment?

\section{Procedure}

A pilot study was conducted before the main quantitative study. The aims of conducting this pilot study were to find out whether the questions were clear or not and understandable enough and to learn whether an addition to the data collection tool was necessary. To conduct the pilot study, the researchers emailed all the pre-service EFL teachers. Out of the $\mathbf{5 8 8}$ teachers, 38 consented to participate voluntarily to the face-toface pilot study. After the piloting procedure, which lasted for a month, the researchers performed minor revisions regarding to language and grammar of the survey. The survey 
link was then put on the online course room and the discussion board and participants were asked to complete the survey thoroughly. If the learner agreed to participate in the study, he/she completed the survey, and then submitted the completed the one-time survey through the secure online link. The participants voluntarily consented to participate in the study without incentives. At the end of the survey, which stayed for a month in the online learning environment, 186 participants were attended the study. To support the primary quantitative data, supportive qualitative data were added. Out of the 186 participants, 2 pre-service EFL teachers were purposefully selected for the one-on-one interviews. The representative pre-service teachers were contacted by telephone for the interview and each interview was scheduled for an hour.

\section{Data Analysis}

The quantitative data analysis was done using the SPSS program for Windows, and content analysis was conducted in order to analyse the qualitative data obtained from the interviews. The answers to each question in the interviews were coded and categorized by the authors.

\section{RESULTS}

\section{Quantitative Data}

Research Question 1: What is the level of self-efficacy beliefs of the pre-service EFL teachers?

Descriptive statistics for self-efficacy belief are presented in Table 3.

Table: 3

Descriptive statistics and Cronbach alpha measures for self-efficacy beliefs scale $(n=186)$

\begin{tabular}{cccccc}
\hline & M & Sd & Min. & Max. & Cronbach Alpha \\
\hline Self-Efficacy Belief & 7.14 & 1.27 & 3.00 & 9.00 & 0.92 \\
\hline
\end{tabular}

The results shown in Table 3 suggest that most of the pre-service EFL teachers in the Distance English Language Teacher Education Program have high efficacy beliefs. That is to say, the pre-service EFL teachers believe that they are efficacious in engaging students learning, managing EFL classes, and implementing instructional strategies. This result is noteworthy as Bandura (1997) stated that teachers' self-efficacy beliefs in their instructional efficacy affect the learning environment. In addition, as Lee \& Yuan (2014) stated, pre-service teachers with high self-efficacy beliefs might be able to think positively of their future teaching practice and feel more motivated towards teaching despite the possible challenges they may encounter.

Research Question 2: What kind of achievement goal orientations do the pre-service EFL teachers have?

Descriptive statistics for achievement goal orientations are presented in Table 4.

Table: 4

Descriptive statistics and Cronbach alpha measures for achievement goal orientations scale $(n=186)$

\begin{tabular}{lllllc}
\hline & M & Sd & Min. & Max. & Cronbach Alpha \\
\hline AGO & 3.60 & 0.93 & 1.00 & 5.00 & 0.89 \\
\hline
\end{tabular}

According to Table 4, results indicated a difference in the pre-service EFL teachers' goal adoptions. These results suggest that the pre-service EFL teachers adopt more than one achievement goal, and mostly mastery goals for learning are adopted. This result can be interpreted as positive since teachers adopting mastery goal orientations seek challenging tasks and do well in difficult situations. However, mastery goal orientations involve the 


\begin{tabular}{|c|c|c|c|c|c|c|c|c|}
\hline & $\begin{array}{l}\text { Engaging } \\
\text { Students } \\
\text { Learning }\end{array}$ & $\begin{array}{l}\text { Managing } \\
\text { EFL } \\
\text { Classes }\end{array}$ & $\begin{array}{l}\text { Implementing } \\
\text { Instructional } \\
\text { Strategies }\end{array}$ & $\begin{array}{l}\text { General } \\
\text { Self- } \\
\text { Efficacy }\end{array}$ & $\begin{array}{l}\text { Mastery- } \\
\text { Approach }\end{array}$ & $\begin{array}{l}\text { Performance- } \\
\text { Avoidance }\end{array}$ & $\begin{array}{l}\text { Performance- } \\
\text { Approach }\end{array}$ & $\begin{array}{l}\text { Mastery- } \\
\text { Avoidance }\end{array}$ \\
\hline $\begin{array}{l}\text { Managing EFL } \\
\text { Classes }\end{array}$ & $0.665 * *$ & & & & & & & \\
\hline $\begin{array}{l}\text { Implementing } \\
\text { Instructional } \\
\text { Strategies }\end{array}$ & $0.704 * *$ & $0.686 * *$ & & & & & & \\
\hline $\begin{array}{l}\text { General Self- } \\
\text { Efficacy }\end{array}$ & $0.890 * *$ & $0.886 * *$ & $0.890 * *$ & & & & & \\
\hline $\begin{array}{l}\text { Mastery- } \\
\text { Approach }\end{array}$ & $0.156 *$ & $0.244 * *$ & $0.207 * *$ & $0.228 * *$ & & & & \\
\hline $\begin{array}{l}\text { Performance- } \\
\text { Avoidance }\end{array}$ & $0.014 *$ & $0.049 *$ & $0.080 *$ & $0.053 *$ & $0.241 * *$ & & & \\
\hline $\begin{array}{l}\text { Performance- } \\
\text { Approach }\end{array}$ & $-0.016 *$ & $0.064 *$ & $0.039 *$ & $0.032 *$ & $0.343 * *$ & $0.703 * *$ & & \\
\hline $\begin{array}{l}\text { Mastery- } \\
\text { Avoidance }\end{array}$ & $0.241 * *$ & $0.205 * *$ & $0.228 * *$ & $0.253 * *$ & $0.653 * *$ & $0.424 * *$ & $0.358 * *$ & \\
\hline General AGO & $0.107 *$ & $0.162 *$ & $0.162 *$ & $0.161 *$ & $0.664 * *$ & $0.824 * *$ & $0.826 * *$ & $0.749 * *$ \\
\hline
\end{tabular}

development of competence through task mastery and the emphasis is placed on developing new skills (Lindsay, 2010).

Table: 5

Difference in the pre-service EFL teachers' goal adoptions

Research Question 3: Is there a relationship between the pre-service EFL teachers' selfefficacy beliefs and achievement goal orientations?

The present study also aimed at exploring the possible association between the subscales of goal orientation and self-efficacy. The results of the third research question revealed the effect of mastery goal on self-efficacy and it showed among goal orientations, mastery goal is also positively but not significantly predicts self-efficacy. Correlation analyses performed between the pre-service EFL teachers' self-efficacy beliefs and achievement goal orientations are reported in Table 5. According to the Table, there are significant correlations at $\boldsymbol{p}<\mathbf{0 . 0 1}$ level among pre-service EFL teachers' self-efficacy subscales and achievement goal subscales. However, as expected, self-efficacy beliefs were correlated to achievement goal orientations $(r=0.16, p<0.05)$. Mastery approach was positively but weakly related to engaging students learning $(r=0.15, p<0.05)$, managing EFL classes $(r=0.24, p<0.01)$, implementing instructional strategies $(r=0.21, p<0.01)$, and general self-efficacy $(r=0.23, p<0.01)$. The results also showed no significant relationship between performance approach and self-efficacy variables. In addition, performance avoidance had no significant relationship to self-efficacy subscales, either. These findings have been found to fit to several researchers' studies (Coutinho \& Neuman, 2008; Eryenen, 2008; Hsieh, Sullivan \& Guerra, 2007). A research done by Coutinho and Neuman (2008) and Zafarmand, Ghanizadeh, and Akbabi (2014) stated that mastery-approach and performance-approach achievement goals were positive predictors of self-efficacy beliefs. However, Elliot and McGregor (2001) reported that mastery-avoidance has positive connection with fear of failure and negative connection related to self-determination. According to these researchers, it seems unlikely that individuals with this goal orientation would have confidence in their ability to achieve desired outcomes. In addition, performance-avoidance 
is generally associated with poor performance, so individuals who routinely perform poorly are unlikely to believe that they have the ability to perform well (Lindsay, 2010).

Research Question 4: Do pre-service EFL teachers' self-efficacy beliefs change according to status of participation in the online learning environment?

According to findings given in Table 6 , there were no statistically significant difference between self-efficacy belief and participation in the online learning environment, $t(184)=$ $-0,111, p=0,912$. It has not been found any study done about the relationship between these variables. However, a study conducted by Sakar (2009) revealed that senior students' frequency of participation to online learning environment in this program was quite low. It can be concluded that attendance to the online courses makes no difference to the selfefficacy beliefs of the pre-service teachers, but in order to understand the exact relationships, more studies are needed.

Table: 6

Self-efficacy beliefs based on status of participation in online learning environment

\begin{tabular}{lcccccc}
\hline & $\begin{array}{l}\text { Participation in Online } \\
\text { Learning Environment }\end{array}$ & $\mathbf{n}$ & $\mathrm{M}$ & $\mathrm{Sd}$ & $\mathrm{t}$ & $\begin{array}{l}\text { Cronbach } \\
\text { Alpha }\end{array}$ \\
\hline $\begin{array}{l}\text { Self-Efficacy } \\
\text { Belief }\end{array}$ & Yes & 78 & 7.13 & 1.22 & & \\
& No & 108 & 7.15 & 1.31 & 0.111 & 0.912 \\
\hline
\end{tabular}

Research Question 5: Do pre-service EFL teachers' achievement goal orientations change according to status of participation in the online learning environment?

As shown in Table 7, statistically no meaningful difference existed between achievement goal orientation and its subscales to status of participation in online learning environment, $t(184)=0,796, p=0,427$. It has not been found any study done in literature yet.

Table: 7

Achievement goal orientations based on status of participation in online learning environment

\begin{tabular}{cclllll}
\hline & $\begin{array}{c}\text { Participation in Online } \\
\text { Learning Environment }\end{array}$ & $\mathrm{n}$ & $\mathrm{M}$ & $\mathrm{Sd}$ & $\mathrm{t}$ & $\begin{array}{l}\text { Cronbach } \\
\text { Alpha }\end{array}$ \\
\hline \multirow{2}{*}{ AGO } & Yes & 78 & 3.67 & 0.78 & 0.796 & 0.427 \\
& No & 108 & 3.56 & 1.02 & & \\
\hline
\end{tabular}

In addition to these questions, pre-service EFL teachers' achievement goal orientations and self-efficacy beliefs are also examined according to gender, age, and work experience variables. As a result of t-test, it was found out that there were not noteworthy findings between pre-service EFL teachers' achievement goal orientations, self-efficacy beliefs and gender, age and work experience. However, these findings were insufficient to note a statistically relationship among these variables.

\section{Qualitative Data}

In one-on-one interviews, open-ended questions below were asked to the pre-service EFL teachers. Data cited from the interviews.

\section{How do you describe yourself as a teacher/student?}

PST $_{1}$ says "I am a hardworking student and teacher... and a quick learner." She also sees herself as a competent learner and therefore she learns efficiently. "I was always a 
successful student and I believe that if you study hard you do wonders." She emphasized that her aim as a teacher was to learn for learning and this is her primary aim. PST 2 says "I am not very smart student but I study all my lessons and I do my best in the exams... Mostly I get average grades ... I am a student like that... that's enough for me." She adds that "If I didn't study and get low grades I felt guilty... I don't want to let my family down... I try hard to make them feel happy."

\section{What are your goals (personal/academic/professional)?}

PST1 personal goal is to finish the school on time. She added "After I graduated I have to study harder to teach better... If I give up studying I couldn't teach effectively... so my goal is to be a perfect teacher." She thought that she is a successful teacher and her grades are proofs for this result. Her academic and professional goals were simple. She wanted to graduate with an honour degree and began to work as an instructor in a public university. She added that a teacher should be enthusiastic and wise. That's why she wants to be an enthusiastic and wise teacher when she begins to work. For academic goal, PST $_{2}$ responded that she wanted to finish the school on time. "The grade point average doesn't matter for me ... I just want to finish my school and make my father happy and believe in me because he doesn't believe that I will finish the school on time." As a personal goal, she says "After I graduate, I want to study in an elementary school because I love kids a lot... And I want to spend all my spare time in my house... with my children... after I graduate I don't want to spend my time with challenging situations, exams... I feel tired of these."

\section{What do you do when you faced a very difficult academic task?}

PST $_{1}$ believes that every teacher can be successful if he/she studies hard. When she faces a difficult task, first she gets the bottom of the subject. If she didn't understand it then she asks her teachers or friends. She emphasized that she never leaves the task incomplete. She says "When I learn, I learn completely." PST 2 says "It is hard for me to deal with that tasks... Mostly I lose my motivation on that occasions... so it is better for me not to think too much on that tasks." She added that she tried to understand and overcome the difficult task but mostly she chose to get it out of her way. "If I do the simple tasks and have an idea about the difficult ones that is enough for me."

\section{What do you think about the relationship between ability and success?}

PST $_{1}$ believes that one can succeed only when he/she studies hard. "This is a psychological situation... I believe that ability is nothing without studying... If the teacher has an ability he/she needs to study to succeed but if he/she has an ability this does not enough for success..." PST 2 responded that "ability is very important factor in success... for example when I am not good at subject or lesson, I know that I cannot do well, so I don't force myself because I know that I don't have the necessary ability." She says "... for example I believe that I don't have much ability in English so I study hard before the exams and mostly I get around 70 points... actually it is enough for me...some of my friends don't study hard and they get $\mathbf{8 0 - 9 0}$ points... I think this is because they have the ability for that."

What do you do when you faced a challenging situation in the classroom?

PST $_{1}$ reported that challenging situations were always big problems for teachers. Moreover, she thinks of the school as her work place. "... and if I am a teacher, I should overcome these situations and establish a management system in the classroom... When I first enter 
a classroom I always explain the students my expectations and warn them about their responsibilities and behaviours". She says "If a student doesn't follow the classroom rules, I speak to him/her separately and warn him/her to follow the classroom rules." According to PST $_{2}$, controlling the challenging situations were very difficult especially with today's students. PST 2 says "when a problem occurs my lesson entirely ruins ... because it takes a lot time to overcome the challenging situations." She adds "when I enter a classroom... I always pray for not to have troubled students because if I have students like these I don't feel happy and I can't motivate myself and the students for the lesson."

\section{What do you do to get students to believe they can do well in English?}

For PST $_{1}$, motivating the students was the first responsibility of a teacher. She says "I always smile to students. I believe that if a teacher smile and feel happy the students then believe in themselves and success. I always remind them that I believe in them." She continues "I get through to all students, and make sure that they understand the lesson... this is very important." PST 2 says "As a teacher I believe in myself and I think every student should believe in himself or herself before the teacher believes in him or her. If a student doesn't believe that he or she can do well...It takes a long time to get him or her to believe... I always say the students that I believe in them... and I motivate them."

\section{How do you react when your students are confused?}

PST $_{1}$ says "I am very patient in that situations.... I provide alternative examples to students, and mostly they understand". She emphasized that she makes the necessary preparations to adjust the lesson to all levels of students. PST 2 says "I know myself and I always do the best to motivate the students and help them understand." She adds "If a student doesn't study before he/she comes to classroom, most probably he/she will not understand the lesson completely and he/she confuses." According to PST 2 "if a teacher and a student take care of their responsibilities, everything will be fine."

Do you participate in online learning environment? If Yes - What is your intend use of online learning environment?

PST $_{1}$ participates in the online learning environment. She says "I try to enter the system every day... I consider myself an active participant". For the second question PST $_{1}$ says "I use the online learning environment because it motivates me and reinforce my learning... If I don't use it, I don't feel myself happy and I feel something missing." PST 2 says "I don't use the online learning environment very frequently... It is not compulsory for us so $I$ just follow the bulletin board sometimes in case of there is something important." And she adds "I don't think it is useful." She also adds "Sometimes I enter the system but I can't find the necessary materials."

The qualitative results revealed that the pre-service EFL teachers have different characteristics and views in terms of goal orientations, self-efficacy beliefs and participating in the online learning environment. The differences exist between mastery and performance goal oriented participants $\left(\right.$ PTS $_{1}$ and PTS 2 ) are shown on table 8. As seen in table 8, the characteristics identify the pre-service teachers in terms of achievement goal orientations, self-efficacy beliefs and perceptions of the online learning environment. 
Table: 8

The characteristics and views of the pre-service EFL teachers about goal orientations, self-efficacy beliefs and participating in the online learning environment

\begin{tabular}{|c|c|c|c|}
\hline Variable & Characteristics & PST $_{1}$ & PST $_{2}$ \\
\hline \multirow{6}{*}{$\begin{array}{l}\text { Achievement } \\
\text { Goal } \\
\text { Orientation }\end{array}$} & Learning aim & $\begin{array}{l}\text { Competence, self- } \\
\text { improve }\end{array}$ & Avoid failure \\
\hline & Motivation & Intrinsic & Extrinsic \\
\hline & Ability & Can be developed & Innate \\
\hline & Effort & To learn & Look-good \\
\hline & Interest in learning & High & Medium/Low \\
\hline & Improvement & Choose challenging tasks & $\begin{array}{l}\text { Choose less challenging } \\
\text { tasks }\end{array}$ \\
\hline \multirow{3}{*}{$\begin{array}{l}\text { Self-efficacy } \\
\text { Belief }\end{array}$} & Students engagement & $\begin{array}{l}\text { Motivate, improve and } \\
\text { believe in sts }\end{array}$ & $\begin{array}{l}\text { Firstly, the sts should } \\
\text { believe in themselves, } \\
\text { motivate }\end{array}$ \\
\hline & $\begin{array}{l}\text { Classroom } \\
\text { management }\end{array}$ & $\begin{array}{l}\text { Control the classroom } \\
\text { easily }\end{array}$ & $\begin{array}{l}\text { Afraid of disruptive } \\
\text { behaviours }\end{array}$ \\
\hline & $\begin{array}{l}\text { Instructional } \\
\text { strategies }\end{array}$ & $\begin{array}{l}\text { Make preparations for } \\
\text { the lesson, implement } \\
\text { alternative strategies }\end{array}$ & $\begin{array}{l}\text { Make preparations for the } \\
\text { lesson, sts have to take } \\
\text { care of their learning first }\end{array}$ \\
\hline \multirow{3}{*}{$\begin{array}{l}\text { Perceptions of } \\
\text { the Online } \\
\text { Learning } \\
\text { Environment }\end{array}$} & Participation & Active user & $\begin{array}{l}\text { Not very much/ not } \\
\text { worthwhile }\end{array}$ \\
\hline & Motivation & $\begin{array}{l}\text { Useful to my learning but } \\
\text { it should be improved }\end{array}$ & $\begin{array}{l}\text { Useful but not necessary. } \\
\text { It is not available when } \\
\text { needed }\end{array}$ \\
\hline & Aim & $\begin{array}{l}\text { Enhance leaning, } \\
\text { reinforcement }\end{array}$ & Follow the bulletin board \\
\hline
\end{tabular}

\section{DISCUSSIONS}

The main purpose of this study was to describe pre-service EFL teachers' self-efficacy beliefs, goal orientations, and participations in the online learning environment. The quantitative and subsequent qualitative data and analysis provided consistent results on these variables. Firstly, self-efficacy beliefs of the pre-service EFL teachers are examined. Considering the results from the quantitative data, pre-service EFL teachers, by and large, believe that they are efficacious in engaging students learning, managing EFL classes, and implementing instructional strategies. This result is noteworthy as teachers' self-efficacy beliefs in their instructional efficacy affect the learning environment (Bandura, 1997; Wyatt, 2013). The interviews and subsequent analysis revealed that high and medium efficacious teachers differ in instructional strategies, students' engagement, and classroom management themes. These differences are close to existing researches (Coutinho, 2008; Egel, 2009; Henson, 2001). At this point, the most effective way of developing a strong sense of efficacy is through mastery experiences, as proposed by Bandura. That is, performing a task successfully strengthens the pre-service teachers' sense of self-efficacy (Zafarmand et al., 2014). On the basis of the interviews, high efficacious teachers seem to enhance the students' performance and success as prior researches have mentioned (Henson, 2001; Tschannen-Moran et al., 1998). Moreover, pre-service EFL teachers' selfefficacy beliefs seem too fragile. In a similar vein, Yuksel (2014) found that pre-service teachers' self-efficacy beliefs are not stable and change at certain stages of teacher education. New experiences and challenges disrupt their pre-existing beliefs and force 
them to reassess their capabilities. However, at the pre-service phase they try to be efficacious but this can change in in-service phase.

Secondly, pre-service EFL teachers' achievement goal orientations are also examined. The pre-service EFL teachers adopt more than one achievement goal, and mostly mastery goals for learning are adopted. These teachers expected to be very successful as their motivations and achievement behaviours are high (Afsaneh \& Safoura, 2015; Dweck \& Leggett, 1988; Elliot, 1999; Yeung, Tay, Hui, Lin, \& Low, 2014). In addition, this is important since teachers adopting mastery goal orientations do well in difficult situations. However, mastery goal orientations involve the development of competence through task mastery and the emphasis is placed on developing new skills (Lindsay, 2010). However, mastery goal oriented teachers are open to change and self-transcendence values (Pudelko \& Boon, 2014). Considering the results from the interviews, the themes namely learning aim, motivation, ability, effort, interest in learning and improvement led to differences when mastery and performance orientations compared. The learning aim and motivation came up as a powerful determiners in adopting goal orientations. The differences between mastery and performance orientations are also stated in literature (Coutinho \& Neuman, 2008; Elliot, 1999; Nitsche et al., 2011; Retelsdorf et al., 2010).

The issue, however, of participation in the online learning environment showed up no statistically significant relationship between achievement goal orientation and self-efficacy beliefs. However, on the basis of interviews, some differences between mastery and performance oriented pre-service EFL teacher were found. The differences between quantitative and qualitative results can be context-based. As discussed in the literature review, self-efficacy beliefs and goal orientations are two important variables that affect pre-service teachers in many ways (Bandura, 1997; Beghetto, 2007). The results of the present study indicated significant relationships between achievement goal orientation and self-efficacy and this result is consistent with the prior researches (Coutinho \& Neuman, 2008; Eryenen, 2008; Hsieh et al., 2007, Minnella, 2010). In addition, this study supported the importance of self-efficacy (Bandura, 1997) and goal orientations (Nitsche et al., 2011) for pre-service teachers.

\section{CONCLUSION}

Based on current self-efficacy and goal orientation research in EFL teacher education and educational psychology, this study explores pre-service EFL teachers' self-efficacy beliefs, goal orientations, and participations in online learning environment, which adds to the existing self-efficacy and goal orientation knowledge in pre-service teacher education process. However, the research is not without limitations. First, the research is limited to Distance English Language Teacher Education program at Anadolu University, in Turkey. Second, the use of asynchronous Web-based management tool in the program could also be a limiting factor. Third, the class structure is another limiting factor. If the class were structured in a different way, the results of the research may be different. Thus in the future, studies should be replicated with a bigger population to better assess and evaluate the relationships between achievement goal orientations, self-efficacy beliefs, and participation in the online learning environment. In addition, qualitative study in a long term may give different and deep results. Mastery and performance goals need further interpretation with male and female balanced studies. Besides, the four quadrants of goal orientations and self-efficacy beliefs need to be studied on a long term. And more research is needed about how these orientations affect the students of these teachers adopting different goal orientations and self-efficacy beliefs. Age and gender issues in goal orientations and self-efficacy beliefs need further studies. Self-efficacy and goal orientation motives are difficult to study. So more focused qualitative studies should be conducted to understand these issues deeply. In addition, there should be qualitative studies that examine the online learning environments effects on pre-service teachers' self-efficacy beliefs and goal orientations. 
Authors' Note: This study has been reproduced from the Master's thesis of Hasan Uçar "Preservice English Language Teachers' Self-Efficacy Beliefs, Goal Orientations and Participation in Online Learning Environment: A Study of a Distance English Language Teacher Education Program" under the supervision of Prof. Dr. Müjgan Yazıcı Bozkaya, at Anadolu University, Graduate School of Social Sciences.

\section{BIODATA and CONTACT ADDRESSES of the AUTHORS}

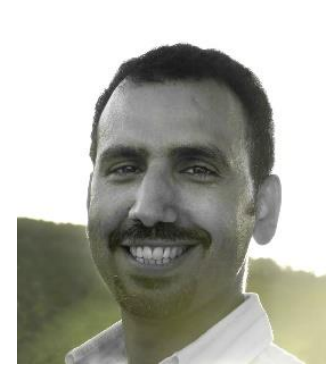

Hasan UCAR is an English language instructor at the Department of Foreign Languages, Bilecik Seyh Edebali University, Turkey. He received his Bachelor's degree from College of Open Education, English Language Teaching Department, Anadolu University. He holds a Master's degree in the Department of Distance Education from Anadolu University. Currently, he is a doctoral candidate at the Department of Distance Education, Graduate School of Social Sciences, Anadolu University. Hasan's current research agenda is motivational design of instruction in online learning environments. Additional areas of research include instructional design/technology, teaching and learning in online technologies, and motivation and engagement of online learners.

\section{Hasan UCAR}

Bilecik Seyh Edebali University, Bozuyuk Vocational School, 11300

Bozuyuk/Bilecik/Turkey

Phone: +90 2282141315

e-Mail: hasan.ucar@bilecik.edu.tr

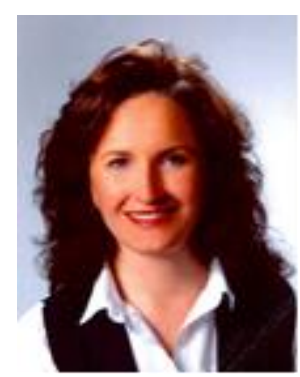

Prof. Dr. Mujgan YAZICI BOZKAYA earned her M.S. and Ph.D. degrees in Communication Sciences from Anadolu University. She is a full Professor at the Open Education Faculty, Anadolu University, Turkey. In her current position, she serves as a Coordinator and an Instructional Designer in Open Education Faculty. Her research interests are Distance Teaching and Learning, Interpersonal Communication, Social Presence, SelfEfficacy, New Technologies and Textbook Design in Distance Education. She has presented in recognized national and international conferences and published scholarly articles.

Prof. Dr. Mujgan YAZICI BOZKAYA

Anadolu University

Open Education Faculty, 26470, Eskisehir, Turkey

Phone: +90 2223350580 / 5880

e-Mail: mbozkaya@anadolu.edu.tr

\section{REFERENCES}

Afsaneh, G. \& Safoura, J. (2015). An exploration of EFL learners' perceptions of classroom activities and their achievement goal orientations. International Journal of Research Studies in Education. 4 (3), 33-45.

Bandura, A. (1997). Self-efficacy: The exercise of control. New York: W. H. Freeman and Company.

Beghetto, R. A. (2007). Prospective teachers' beliefs about students' goal orientations: A carry-over effect of prior schooling experiences? Social Psychology of Education, 10, 171-191. 
Butler, R. (2007). Teachers' achievement goal orientations and associations with teachers' help seeking: Examination of a novel approach to teacher motivation. Journal of Educational Psychology, 99 (2), 241-252.

Chacon, T. C. (2005). Teacher' perceived efficacy among EFL teachers in middle schools in Venezuela. Teaching and Teacher Education, 21 (3), 257-272.

Coutinho, S. (2008). Self-efficacy, metacognition, and performance. North American Journal of Psychology, 10 (1), 165-172. Retrieved March 11, 2012, from,http://findarticles.com/p/articles/mi_6894/is_1_10/ai_n28518811/

Coutinho, S.A. \& Neuman, G. (2008). A model of metacognition, achievement, goal orientation, learning style, and self-efficacy. Learning Environment Research, 11,

Cresswell, J. W. (2012). Educational research: planning, conducting, and evaluating quantitative and qualitative research. Fourth edition. Pearson: Boston, MA. 131-151.

Daal, S., Donche, V. \& De Maeyer, S. (2014). The impact of personality, goal orientation and self-efficacy on participation of high school teachers in learning activities in the workplace. Vocations and Learning, 7, 21-40.

Dweck, C. S. \& Leggett, E. L. (1988). A social-cognitive approach to motivation and personality. Psychological Review, 95 (2), 256-273.

Egel, I. P. (2009). The prospective English language teacher's reflections of self-efficacy. Social and Behavioral Sciences, 1, 1561-1567.

Elliot, A. J. (1999). Approach and avoidance motivation and achievement goals. Educational Psychologist, 34 (3), 169-189.

Elliot, A. J. \& McGregor, H. (2001). A $2 \times 2$ achievement goal framework. Journal of Personality and Social Psychology, 80 (3), 501-519.

Elliot, A. J. \& Murayama, K. (2008). On the measurement of achievement goals: Critique, illustration, and application. Journal of Educational Psychology, 100(3), 613-628.

Eryenen, G. (2008). The relationships between goal orientations, academic self-efficacy, and teacher sense of efficacy and predictive roles of these variables on pre-service teachers' academic achievement. Unpublished master's thesis. İstanbul: İstanbul University.

Henson, R. K. (2001). Teacher Self-Efficacy: Substantive Implications and Measurement Dilemmas, Paper Submitted in Annual Educational Research Exchange Conference, Texas A. M. University, 1-43.

Hsieh, P.; Sullivan, J.R. \& Guerra, N.S. (2007). A close look at college students: Selfefficacy and goal orientation. Journal of Advanced Academics, 18 (3), 454-476.

Kucsera, J.V.; Roberts, R.; Walls, S.; Walker, J. \& Svinicki, M. (2011). Goal orientation towards teaching (GOTT) scale, Teacher and Teaching: theory and practice, 17(3), 597-610.

Lee, I. \& Yuan R. (2014). Motivation change of pre-service English teachers: a Hong Kong study. Language, Culture and Curriculum, 27(1), 89-106.

Lindsay, P.C. (2010). Assessing the relationships among goal orientation, test anxiety, self-efficacy, metacognitıon, and academic performance. Unpublished master's thesis. İllionis. University of North İllionis.

McMillian, J.H. (2004). Educational research: fundamentals for the consumers. Fourth edition. Pearson: New York.

Minnella, J. M. (2010). Achievement goals, self-efficacy, metacognitıon, and learning strategies as predictors of asynchronous learners' academic success. Unpublished doctoral dissertation. Capella: University of Capella. 
Nitsche, S., Dickhäuser, O., Fasching, M.S., \& Dresel, M. (2011). Rethinking teachers' goal orientations: Conceptual and methodological enhancements. Learning and Instruction, 21(4), 574-586.

Pajares, M. F. (2002). Overview of social cognitive theory and of self-efficacy.Retrieved May 19, 2012, from, http://www.emory.edu/EDUCATION/mfp/eff.html

Pudelko, C. E., \& Boon, H. J. (2014). Relations between Teachers' Classroom Goals and Values: A Case Study of High School Teachers in Far North Queensland, Australia. Australian Journal of Teacher Education, 39(8). Retrieved from http://ro.ecu.edu.au/ajte/vol39/iss8/1

Retelsdorf, J.; Butler, R.; Streblow, L. \& Schiefele, U. (2010). Teachers' goal orientations for teaching: Associations with instructional practices, interests in teaching, and burnout. Learning and Instruction, 20, 30-46.

Sakar, N. (2009). Online course support in distance learning: Student evaluation of English language teaching Bachelor of Arts program. Turkish Online Journal of Distance Education, 10 (2).

Tang, E. L., Lee, J.C., \& Chun, C. K. (2012). Development of teaching beliefs and the focus of change in the process of pre-service ESL teacher education. Australian Journal of Teacher Education, 37(5). http://dx.doi.org/10.14221/ajte.2012v37n5.8

Tschannen-Moran, M.; Hoy, A. W. \& Hoy, W. K. (1998). Teacher efficacy: Its meaning and measurement. Review of Educational Research, 68 (2), 202-248.

Tschannen-Moran, M. \& Hoy, A. W. (2001). Teacher efficacy: Capturing an elusive construct. Teaching and Teacher Education, 17(7), 783-80.

Wyatt, M. (2013). Overcoming low self-efficacy beliefs in teaching English to young learners, International Journal of Qualitative Studies in Education, 26 (2), 238-255.

Yeung, A. S., Tay, E., Hui, C., Lin, J. H. \& Low, E. (2014). Pre-service Teachers' Motivationin Using Digital Technology. Australian Journal of Teacher Education, 39(3). http: //dx.doi.org/10.14221/ajte.2014v39n3.1

Yuksel, G. H. (2014). Becoming a teacher: tracing changes in pre-service English as a foreign language teachers' sense of efficacy. South African Journal of Education, 34 (3).

Zafarmand, A., Ghanizadeh, A. \& Akbabi, O. (2014). A structural equation modeling of EFL learners' goal orientation, metacognitive awareness, and self-efficacy. Advances in Language and Literary Studies 5(6). 112-124. 